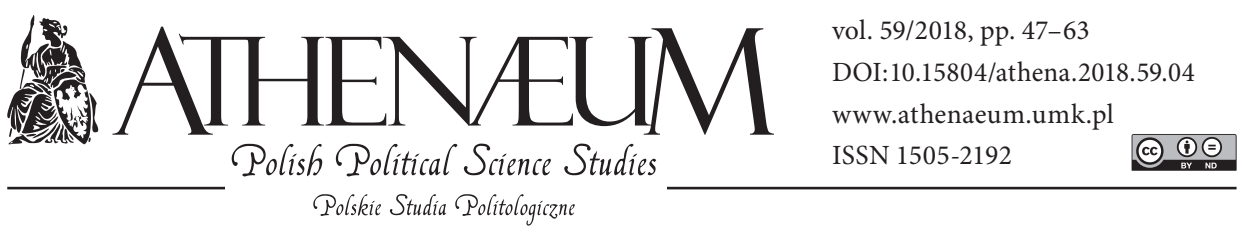

\title{
DEIFICATION OF MAO ZEDONG'S IMAGE AND AN ICONOCLASTIC ATTEMPT AT ITS DECONSTRUCTION
}

\author{
DEIFIKACJA WIZERUNKU MAO ZEDONGA \\ I OBRAZOBURCZA PRÓBA JEGO DEKONSTRUKCJI
}

Maciej Szatkowski*

\begin{abstract}
This text is an attempt to reflect on the image of Mao Zedong in People's Republic of China and the politics of shaping his image. Mao Zedong, his politics, literary work, life, and other aspects of his long biography have been fairly well described by numerous researchers over the past few decades. However, far too little space has been devoted to the image of Mao Zedong in the consciousness of the Chinese.

Considering that Mao has been included into the set of deities and surrounded by a halo of divinity, the critical attitude to his figure verges on sacrilege. It is a surprising encounter of politics and religion, which Mao Zedong would not expect in his lifetime. In fact, only popular and avant-garde art, as well as individual oppositionists have made iconoclastic attempts to deconstruct the figure of Mao.
\end{abstract}

Keywords: Mao Zedong, Chinese art, iconoclasm, cult of personality, deification
Niniejszy tekst jest próbą refleksji na temat wyobrażenia Mao Zedonga w Chinach Ludowych oraz polityki kształtowania jego wizerunku. Mao Zedong, jego polityka, twórczość literacka, życiorys i inne aspekty długiej biografii zostały dość dobrze opisane przez licznych badaczy na przełomie ostatnich kilkudziesięciu lat. Zdecydowanie za mało miejsca poświęcono wizerunkowi Mao Zedonga w świadomości Chińczyków.

Przy założeniu, że Mao został włączony w poczet bóstw i otoczony jest nimbem boskości, stosunek krytyczny do jego postaci staje się obrazoburczy. Jest to zaskakujące spotkanie z pogranicza polityki i religii, którego Mao Zedong nie spodziewałby się za życia. Właściwie tylko sztuka popularna i awangardowa, a także poszczególni opozycjoniści podjęli się ikonoklastycznej próby dekonstrukcji postaci Mao.

Słowa kluczowe: Mao Zedong, sztuka chińska, ikonoklazm, kult jednostki, deifikacja

* Nicolaus Copernicus University in Toruń, Faculty of Languages. 
Chinese idols are easily interpreted as reflections of social desires. They gain the status of idols of the masses, demi-gods and deities. They symbolise the era in which they happened to live. Looking at the most recent Chinese history, especially the second half of the $20^{\text {th }}$ century, we find several figures among those most important in the consciousness of the entire society which arouse its appreciation and admiration, such as Lei Feng. This soldier, who lived only to the age of twenty-two, became famous owing to his total dedication to the welfare of the new society and willingness to commit himself to social acts. He died in 1962 in a road accident. In 1963, his journals were published, and his biography quickly became a work of communist hagiography. Chairman Mao himself called on people to "learn from Lei Feng". Images of Lei Feng occupy the public space to this day, he is widely known and admired, and official propaganda presents him as a symbol of faithfully serving his homeland and the people. However, unofficially his biography and even his actual existence are questioned.

In the late 1970s, songs by Deng Lijun from Taiwan rose to popularity in China. The singer gained enormous popularity in East and Southeast Asia, but it was in People's Republic of China that she was surrounded by a pop-star cult. After years of Maoist rule, and closure to outside culture - including popular culture - the Chinese fell in love with music which talked about love, friendship and life. Deng Lijun's music accompanied the Chinese as they were emerging from the difficult years of constant revolution, opening to the outside world and the first achievements of the free market. Her untimely death in 1995 caused many to despair.

The $1990^{\mathrm{s}}$ was a period of enormous popularity of television and film stars, mainly from Hong Kong (such as Stephen Chow and Andy Lau). In the late 1990s and subsequent years, the accumulation of pop stars was so great that it is hard to speak of mass worship of one person, as it became rather diversified. In the $21^{\text {st }}$ century, a new trend appeared: participation in building the image of business icons. Among them the most important are Jack Ma, the founder of the Alibaba Group, or Zhang Chaoyang, the founder of Sohu (Xin, 2009, p. 3).

Among those who have stood out in the consciousness of the Chinese society in the $20^{\text {th }}$ century is Mao Zedong, the father and founder of the People's Republic of China. He has enjoyed the greatest popularity and adoration, and his person and image have been the centre of a constant, religious and para-religious cult for several decades, with varying intensity. The first leader of the People's Republic 
of China is also the main symbol and historical cement of the Communist Party of China, where Mao legitimises hegemonic rule. The Party itself protects the image of Mao and has custody and control of the political and historical cult.

Monika Umińska in her „Note from the Translator” accompanying her Polish translation of Eric Voegelin's Das Volk Gottes [The People of God] is right in pointing out that politics should not be studied without taking into consideration religious experiences and raptures (Umińska, 1994, p. 5). In political societies the sacred and the profane often overlap and it is on this phenomenon that this article is focused.

The burning of books during the Cultural Revolution was directed against the intellectual values associated with the bourgeois. Eric Voegelin referred to the destruction of literary and artistic culture in terms of calling for a spiritual renewal (Voegelin, 1994, p. 25). We might assume therefore that this phenomenon also gave way to the emotions related to the sphere of the sacred. The staunch adherents of Maoism, firmly believing in his ideas (this belief may have resulted from the idea of tianzi, 'the son of heaven', deeply ingrained in Chinese culture), felt as if they were sinless and beyond reproach. Hence the notorious brutality of the Red Guard, the most obdurate supporters of Mao, which left its mark during the Cultural Revolution. Voegelin, in his discussion of such attitudes, wrote that they were a manifestation of mysticism blended with animalistic aggression. The underlying assumption of people involved in such activities is that even the most hideous crimes form part of the divine plan of saving the world from evil (1994, p.76).

Ryszard Skarżyński in his article about Voegelin's political gnosticism wrote that "the gnostics believe that the existing world is evil, while man is capable of building a new and better society. They pay no attention to the actual reality, instead they focus on an alternative world..." (Skarżyński, 1998, p. 30). Mao was to help in building a new world: his help extended even to those who apart from their blind faith had no other competences to make it happen.

Mao Zedong was born in 1893 and was a member of the Communist Party of China since its foundation in 1921. He was at the helm of the Chinese Soviet Republic in 1931-1934, and later led the Long March to the Yan'an base, where Chinese communists were stationed in 1935-1948, and which is known as the cradle of the Communist Revolution in China. It was there that Mao wrote key treatises and manifests and prepared to overcome the Kuomintang and seize power in China. In 1949, standing on the terrace of the Tian'anmen gate, he proclaimed the existence of the People's Republic of China under his 
leadership. In this way he ended a century of humiliation which his nation had been going through since 1839 and the Opium Wars. He carried out several anti-bourgeois and anti-right-wing campaigns, and crushed the opposition within the Party. However, after the failed Great Leap Forward and its tragic consequences, he was removed from power for several years. In 1966, together with the Gang of Four he unleashed the Cultural Revolution in China, which broke the spine of Chinese culture and changed the Chinese society forever. At the centre of the Cultural Revolution activities was the boundless devotion to Mao Zedong, cementing the cult of personality. During the revolution, it was Mao who became the centre of the Chinese world, its sun and its only god. As all signs of religiosity were officially condemned, religious feelings and servile acts were redirected towards Mao Zedong. The society filled the spiritual vacuum by pouring its religious feelings onto Mao Zedong, who took on divine qualities in the narrative and in the visual sphere. The cult of personality created a new, servile, secular religion. The youth, who were the axis of the revolution, in paintings from the period turn towards the figure of the Great Helmsman like sunflowers towards a red sun, and over Mao's head a sunny glow shines like a halo. Mao from the propaganda posters was taller than others, hovering slightly above the surface, well-built and imperious (e.g., on the poster Chairman Mao Swims Across the Yangzi). In the universal consciousness of those quoting the book of the Red Guards, Mao was omniscient and almighty. He was a combination of Stalin and Lenin (from the revolutionary period), and commanded boundless dread, gratitude, admiration, adoration and blind faith of the people in his mission.

Mao Zedong prepared ground for the cult of personality, introducing statelicensed iconoclasm. During the Cultural Revolution, he ordained a fight against four relics, i.e., old concepts, old habits, customs and culture. Its purpose was to fight against superstition and religious rituals. Monks and nuns were persecuted and re-educated in labour camps. During the Cultural Revolution, temples of all faiths were destroyed (particularly brutally in Tibet), and manifestations of religiosity were eradicated. China was to become a completely atheist state. Religion was ridiculed, and religious practices considered superstitious and wasteful. According to Marx, religion is the opium of the people, of the poor. After introducing communism and overcoming poverty in the society, there was to be no place for it. Cultural Revolution was also a time of fighting against Confucius; Mao officially declared a campaign against Confucius and Lin Biao (the Criticize Lin, Criticize Confucius campaign). However, attempts to remove 
him from Chinese culture had been made earlier, i.e., in the second decade of the $20^{\text {th }}$ century, by the New Culture Movement.

After 1949, China was officially to end individual cults, including the cult of ancestors. Mao's thought was to be the centre of the society's interest, supplemented with Marxism and Leninism (Xin, 2009, p. 1). During the Cultural Revolution, a nationwide, state-sanctioned and public cult of personality was developed. It contained some elements of para-religious nature, for instance, gatherings in Tian'anmen Square in the form of a pilgrimage to the heart of China, meetings with the ruler anointed by the mandate of heaven, trips around Shaoshan (the birthplace of Mao, the Chinese equivalent of the meaning of Bethlehem for Christians), and fanatic readings of the Little Red Book as well as its pious recitation. For the first time in history, due to the total condemnation of all forms of religiousness, a figure with qualities of a monotheistic god emerged in China. The cult of Mao had its religious articles, embedded in political and pop culture - the Little Red Book, songs, poems, and hagiography, and even metal badges. It is estimated that 3 to 5 billion of the badges have been produced. He himself identified the cult of personality with feudal emperors, a connotation which could indeed have been a burden to him, but he never acted against it.

During the Cultural Revolution, Mao took place of the ancestral portraits. People started to identify him with the Confucian order of son's obedience to his father (order of the father and son). It could be said that Mao replaced the emperor and other paternal and patriarchal authorities. In China, there has been a long tradition of good officials who are righteous and kind as parents, so-called fumu guan (Steinmuller, 2015, p. 91).

Mao accepted the cult of personality, and in a conversation with Edgar Snow stated that Khrushchev fell because he had completely cut himself off from the cult of his predecessor. It seems, however, that Mao did notice that things went in the wrong direction during the Cultural Revolution, as in the $1970^{\text {s }}$ he criticized Lin Biao and Chen Boda for an excessive cult of his person (Keith, 2004, p. 2).

Mao Zedong's death in September 1976 drove several hundred million Chinese people to despair, although some felt liberated. The Chinese feared this new era, and were unsure whether they, Mao's children, would cope in the new times. For some, the death of Mao was the death of a god. Although he was not publicly held accountable for all his faults, in some ways his policy was officially revised. The Gang of Four was arrested, tried, and blamed for all the harm inflicted by the Cultural Revolution. People put in labour camps by Mao 
were rehabilitated and released, some after more than twenty years, i.e., since the Hundred Flowers Campaign. Under the leadership of Deng Xiaoping the party adopted the official position that Mao Zedong should be respected for his great achievements in the construction of the socialist state, and that permissible criticism of his policies may not reach $30 \%$ of any oral or written statement on the topic. In 1981, the Party admitted that although Mao made "big mistakes", his merits outweighed them (McGregor, 2013, p. 275). After his death, the cult continued and became sanctioned when Mao Zedong's mausoleum was placed in the central point of China, Tian'anmen Square, in 1977. The many visitors to the mausoleum experience religious raptures. Mao has been embalmed and he is the guardian of state ideology in the square, while his portrait hangs at the Tian'anmen gate, on the opposite side, clearly designating the official state ideology. The image of Mao is protected by state. In addition, as of 2001 all banknotes of the Chinese yuan bear his likeness, and the country is strewn with Mao's monuments. Joanna Wardęga calls Mao a deity of a nationalist religion (2014, p. 16). Mao Zedong used nationalist tones quite efficiently, seeing enemy forces overseas, and giving the public easy answers to threats - frequently ones he invented. It was classic management by fear. He carried out numerous brutal campaigns to eliminate doubters, but also completely random individuals, with which he achieved total subordination of the society. Chinese Marxism was rather quickly sinicised, and the result of this was an unusual hybrid, referred to as socialism with Chinese characteristics. Communism does not have a homeland, but in the Chinese case Mao organised a nationalist realm for it (although generally without chauvinism, in the spirit of the May Fourth Movement), he himself becoming the national god.

The cult of Mao is also used in plays within the Party. One famous instance was that of the cynical First Secretary of the Party in Chongqing, Bo Xilai, who rather efficiently used the Maoist resentment. He created a strong propaganda machine, reinforcing his own authority. He initiated a campaign of singing songs from the period of the revolution (changhong), organised so-called red trips to places sacred with the blood of communists, and sent residents of the city text messages with Mao Zedong quotations. He made an attempt to revitalise the political worship of Mao. These actions resembled the nucleus of a small cultural revolution which, however, did not develop further. The danger lay in the fact that Bo was mentioned as a candidate for a narrow group of the Chinese politburo, collectively wielding power in China. In some circles, he was seen as the successor of Xi Jinping. The chances of Bo's career ended with his spectacu- 
lar fall, associated with a criminal and political scandal' ${ }^{1}$. Following this event, a discussion began regarding the strength of Mao's image and the possibility of earning political capital through it. Bo's case reveals the political and religious worship of the man. Some older people warmly remember Mao's era, as it fell on the time of their youth. It was then that they were infected with a virus of propaganda, which promised them life in a paradise on earth.

Due to the lack of religious orthodoxy, Mao was added into the set of deities from the bottom up, without any sanctification procedure or an official decree. Formally, he is not a Taoist deity found in the liturgical writings or recognised by Taoist scholars and priests, but his popular cult is thriving. As a new deity Mao is caring, therapeutic, and not necessarily liturgical or meditative. Through political and popular worship Mao has simultaneously become a Confucian and Taoist being.

Some of the rich have private chapels in their homes with a statue of Mao Zedong. $26^{\text {th }}$ December - his birthday - is the day of pilgrimages to Shaoshan, which has become a sanctuary of a kind, and the day is known as Mao Zedong Shengdanjie (which translates as "the birthday of a saint") (Wardęga, 2014, p. 257). Tourists visiting Mao's mausoleum or Shaoshan perform the traditional bow, the kowtow, in front of Mao's monument and body. In temples which hold Mao's statues, gifts are laid down, typically a glass of vodka and burning cigarettes (which resembles the burning of incense), with which Mao is associated.

Especially in Hunan, the province where he came from, Buddhist and Taoist temples often have a statue of the Great Helmsman, covered with yellow cloth (the color of the emperor and the Buddha), where incense, fruit, paper money (false) are offered as if to a god or the spirit of an ancestor (Mao Zedong, A Prosecutor of Religions, Is Now Worshipped Like a God, 2016).

Trade in merchandise with Mao's image, such as mugs, stamps, and coasters, is thriving. Books in the form of hagiographies are published regularly, there are television series produced, and on the occasion of holidays and important anniversaries, the official double (in recent years a woman) makes an appearance. In public transport or private cars it is common to find talismans with the likeness of Mao, which are supposed to ensure a safe journey.

In recent years, the CPC and President Xi Jinping have been avoiding any criticism of Mao, wishing to avoid renouncing the cult of personality, as was the

1 More on the criminal activity of Bo Xilai and his circle in: Wenguang \& Pin (2015). 
case with Joseph Stalin in the Soviet Union. Mao legitimises their undemocratic power; it is therefore in the interest of China's leaders to protect his image. Nevertheless, President Xi, seeing that the cult is growing, has stated that leaders are not gods (Wardęga, 2014, p. 257). Richard McGregor writes that in connection with the $110^{\text {th }}$ anniversary of Mao's birth, there have been voices, mainly abroad, suggesting that Mao's body is removed from Tian'anmen Square and buried in his hometown of Shaoshan (2013, pp. 261-264).

However, we should look for the cult of Mao more deeply than in the ubiquitous propaganda. In his book Rhetoric and Ritual in China's Cultural Revolution the author Daniel Leese writes: "The worship of religious or secular leaders has not been limited to the twentieth century. The emperor had been worshiped as the Son of Heaven, (however limited to the rituals and ceremonies conducted at the imperial court)" (2011, p. 5).

It has been traditional in China to believe in the mandate of heaven. The Son of Heaven, who held the power, enjoyed heavenly favour. However, if he ruled badly, the heaven sent signs, typically natural disasters, heralding his imminent loss of power. A few months before Mao Zedong's death in Tangshan, a powerful earthquake occurred, during which at least 250,000 people lost their lives. The earthquake showed that the idea of the mandate of heaven was still deeply rooted in the Chinese people, despite a battle against superstitions and feudal rituals, as they started to talk about Mao's loss of mandate to exercise power given to him by heaven. Shortly after his death, Mao began to be perceived as an auspicious (jixiang) anthropomorphic deity who brought good fortune, revealing the symbolic culture of the Chinese people. Functions attributed to Mao's image are both magical (in the folk religiosity version) and sentimental (in the political narrative layer). Mao can also be an auspicious representation (jixiangtu'an), found on doors, gates, keyrings or in taxis. Mao is an image, an identity symbol which is strictly national, or even racial and ethnic, and the syncretism of Chinese people is so tolerant that it allows for the inclusion of Mao into the set of deities.

In Chinese, an idol translates as ouxiang and iconoclasm as dapo ouxiang zhuyi, literally "the idea of destroying an idol". In the $20^{\text {th }}$ century, such movements have taken place in China, but quite unexpectedly they have now also reached Chairman Mao, a figure surrounded by the cult of personality and sacred by the cult of popular piety.

The apotheosis of Mao Zedong does not apply to the whole society. On the margins of mainstream art, the so-called main melody (zhuanxuanlü), critical art has emerged, seeking to redefine the image of the Great Helmsman. For the soci- 
ety, such an attitude towards the "father of the nation", a sanctified political and quasi-religious deity, is iconoclastic. The article cites only a few cases, including the best-known ones. Many instances of insulting Mao have not been included here, for example jokes circulating online, amateur theatre performances and cabarets, or many literary examples, particularly items published abroad, as they are not affected by censorship.

Chinese independent PEN Club tries to regularly publish names of people convicted of political views and their expression on its website. Among these stories we find that of the internet writer and blogger Liu Yanli, accused of suspected defamation for her private messages on WeChat, in which she dared to criticise the deceased Mao Zedong and Zhou Enlai, but also the current President of China, Xi Jinping. In October 2014, the New York Times reported the arrest of the octogenarian Chinese writer Tie Lu for the publication of testimonies and memories of people (elderly or deceased) regarding the reign of Mao Zedong, as well as critical essays about the chairman. He was accused of, e.g., "creating a disturbance". The writer was collecting memories of the so-called right-wingers, who had been exiled to the laogai - labour camps, as early as in 1957, after the Hundred Flowers Campaign (Buckley, 2015).

Another case which reverberated widely was that of the Shandong Jianzhu University Professor Deng Xiangchao, who retweeted a post satirising the late Chairman. He was immediately dismissed from the University, and protests of Maoist militias, probably formed outside of the university, broke out on the campus (Lecturer Fired in China's Shandong Province After He Criticized Chairman Mao, 2017).

However, the best-known case turned out to be a recording of the star of Chinese public television, Bi Fujian, popular throughout China for having repeatedly had the privilege of presenting the New Year gala on the Chinese CCTV channel. In a recording from a private dinner leaked onto the internet Bi says: "Uh, don't mention that old son of a bitch, he tormented us!", believed to be a reference to Mao, as he sang lines from Mao-era opera Taking Tiger Mountain by Strategy while entertaining his friends. Mr. Bi apparently thought he was amusing just a few guests around a banquet table, peppered the lyrics with sarcastic asides (Buckley, 2015). Soon after the video was leaked online, Bi was accused of "political sacrilege" and historical nihilism. Repentant Bi apologised for his behaviour and submitted the self-criticism expected by the authorities. We can guess that he hurt political feelings, and those in power proved to be extremely sensitive to this kind of mockery, as it happens in strongly religious societies. 
It should also be noted that Chinese left-wing intellectuals are becoming the guardians of Mao's political image, defending the legacy of his thought. In a society corroded with social injustice, unfairly collected fortunes, scorned internal migrants, and free-market economy, there is room for the political left. It is often in opposition to the government, which finds it hard to fight against it, because it is difficult to negate its communist and communising theses - especially if they refer to the words of Mao. The new Chinese left references Maoist class struggle in the society where, according to many, castes have emerged, similar to the Indian society ( $\mathrm{Lu}, 2014)$.

The best-known and most literal defiant act was splashing red paint on the picture of Mao Zedong on Tian'anmen gate in the spring of 1989, during student protests. Three protesters first unfolded banners with the slogans Time to End the Five Thousand Years of Autocracy and Time to End the Cult of Personality under the portrait of Mao, and then poured paint over it. This event outraged even the students proposing democratisation of the party and fight against corruption in the country. They cut themselves off from those who desecrated the image of Mao, declaring that they did not want to overthrow the system. The protesting students quickly covered the portrait of Mao, to protect the desecrated image from the eyes of those gathered around it. The main organiser of the action was sentenced to life imprisonment, and the remaining two received the sentence of 16 and 20 years in prison. They were released early and found political asylum in the United States and Canada. After 1989, there were at least three attempts to destroy the portrait of Mao in Tian'anmen Square; the fate of those captured by the police remains unknown.

The most famous Chinese artist Ai Weiwei directed a middle finger towards the portrait of Mao in a photo from his series "Fuck off", exhibited in Shanghai in 2000. Ai shows the middle finger in the most famous places of the world, such as the Eiffel Tower, the White House, or the Mona Lisa painting. It was argued that the finger is directed towards the Forbidden City, the symbol of feudal oppression. It is not entirely clear what the author meant; it is left to the interpretation of the audience. It was not Ai Weiwei's first activity under the portrait of Mao Zedong. A few years earlier, in 1994, Ai Weiwei's wife Lu Qing posed for her husband's photos with her skirt raised, exposing her underwear, at the gate - that is under the portrait of the Great Helmsman (Coonan, 2011).

The work of Ai Weiwei which is most saturated with meaning is his "Sunflower Seeds", first shown in Tate Modern. It cannot be directly called an iconoclastic work, as it does not use the literal image of Mao. However, it contains a variety 
of symbols contained in the porcelain sunflower seed. Ai Weiwei engaged the Chinese town of Jingdezhen to produce 100 million such seeds. They were then transported to London and spilled in the Turbine Hall. The visitors could walk on the scattered seeds, lie down on them, run their fingers through them, smell them, etc. Thanks to word play, it was possible to directly touch China (china), notice the senselessness of the work done by the Chinese workers-artists, participate in the consumer's digestive tract, and realise that the production and manufacture is sometimes unnecessary and nonsensical. However, for Ai Weiwei and the Chinese the work had also an additional meaning. Chairman Mao was the sun, and the nation, mostly his faithful young followers and the Red Guard, were like sunflower seeds. They turned to him like sunflowers turn towards the sun. The work was displayed in many places in the world, including Beijing. Abandoned by the sun, the seeds are devoid of their meaning (Debin, 2018). But there is one positive association with sunflower seeds and the difficult period of the Cultural Revolution: "Yet Ai remembers the sharing of sunflower seeds as a gesture of human compassion, providing a space for pleasure, friendship and kindness during a time of extreme poverty, repression and uncertainty" (The Unilever Series: Ai Weiwei: Sunflower Seeds: Interpretation Text).

Insulting and ridiculing Mao Zedong in art can be interpreted as artists' revenge for the many years of imposed socialist realist style, lack of creative freedom, and persecution. Today Mao Zedong is the subject of mockery in avantgarde art, he is processed and deconstructed. With the introduction of market economy (quasi free-market), China opened to Western cultural trends, and to postmodernism and avant-garde, which boldly began to comment on politics and history. The experiences and memories of artists from the period of Mao's government, dissent to his hallowed image and a retaliation of a kind caused them to play with the leader's image, placing it in new contexts and processing it in a postmodern way. What is noticeable in these works is pastiche (using the so-called red humour), a carnivalized image of Mao, or including it in the circuit of pop culture. Gaudy art, pop avant-garde and political pop joined in on the deconstruction of Mao's image with particular enthusiasm. It has therefore often been the object of queer and camp art. The process began at the end of the $1980^{\text {s }}$ and remained quite intensive for several years. A trend of scars and wounds has emerged in literature and the fine arts, that is, a trend of calling to account for the traumas, experienced or inherited, from the past years of Mao's rule. Writers, rebelling against the official historical narrative, have created their own, so-called new historical novel, reinterpreting history and using individual experience. 
Wang Guangyi, a representative of the Chinese cynical realism, in his 1987 work Mao Zedong was one of the first to take on the image of Mao (Li, 2010, p. 164). In the painting, Mao has been placed behind a black grid, and the association with the Chairman behind bars is obvious. Another series of works, Great Criticism, incorporates elements of the new reality into propaganda posters from Mao's era, mostly foreign brands associated with getting rich and with the free market. Posters showing workers, farmers and soldiers in the socialist realist style bear names of the likes of Kodak, Chanel, and Coca-Cola. Thus, Wang Guangyi undermines the meaning of the whole period of revolutionary struggle. According to Lidia Kasarełło, it is a juxtaposition of two conflicting doctrines within a single image (2011, p. 215). There have been two trends in political pop: one, represented by Wang Guangyi, concentrating on iconoclasm, and the other sarcastically decorating his image, as in the art of Yu Youhan. For Yu, Mao is a jovial leader, he uses folk motifs, traditional New Year images, etc.

It is important to note the work of Li Shan. In his paintings, Mao is a pastiche or an allegory, with flowers flowing out of his mouth. The greatest symbol of communist China has become the most important fetish, which has shown the vitality of the symbolic culture in China, and the need to appeal to signs, which gives Mao's image magical, sentimental function, and assigns a semantic function to the language of art (Kasarełło, 2011, p. 216). The artist boldly interferes with the image of Mao Zedong, changes the colour of his face or hat, paints his lips and decorates the image with flowers. In this way, Li Shan comments on the folk and political deification of the Chairman's image, sarcastically referring to it himself. "By negotiating his own personal and sexual identity within the most iconic portraits of Mao, Li Shan visualizes his shifting role from passive receptor to active manipulator in the space of the same image and provides a telling instance of the contradictory set of emotions still attached to the icon by millions of people" (Dal Lago, 1999, p. 56).

$\mathrm{Li}, \mathrm{Yu}$ and Wang are the most famous creators deconstructing the image of Mao, however, there are numerous more subversive works, directly accusing Mao and desecrating his image. Zhu Wei's work is definitely worth mentioning. China Diary No. 1, where Mao is at the same time a rock star, about to perform in front of an audience blindfolded. However, the atmosphere of the image is reminiscent of public criticism, where an overpowered Mao is to be judged by the crowd. Public criticism gatherings, which led to lynches, were an integral part of Chinese reality under the rule of Mao. 
Also worth a note is Counterrevolutionary Slogan by Liu Anping, "in which the author impersonates Mao in the form of his official portrait and reenacts one of the most defiant acts performed during the 1989 demonstrations - the defacement of Mao's portrait hanging on Tian'Anmen Gate. [...] By reenacting this episode, Liu exposes how the harsh punishment imposed on the vandals revealed Mao's still sacrosanct status in the eyes of Chinese rulers" (Dal Lago, 1999, p. 54).

A separate issue is the pictures of Zhang Xiaogang and Yue Minjun not relating directly to the image of Mao Zedong, but quite clearly criticising the havoc which the age of the Great Helmsman wreaked in the society. In the images, the rule of Mao echoes loudly. In the works of both painters (particularly in Zhang's series Bloodlines and Yue's Smiling Faces) we see people-clones, atomic units, which in a way are permanently trapped in post-Maoist reality. These artists can be interpreted as Nestbeschmutzer, who disregard the nation or accuse it of participation in events uncomfortable in its memory. Naturally, such attempts met with censors' reaction and indignation of a part of the society, but we should bear in mind that this art was mainly directed to the West or to a small group of Chinese recipients of contemporary and avant-garde art.

In the avant-garde theatre of Meng Jinghui, which has enjoyed great popularity among city audience and had artistic ambitions, there are several elements of deconstructing Mao's cult ${ }^{2}$. In 1998, Meng staged Accidental Death of an Anarchist by Dario Fo. The director called the spectacle a presentation of the "people's theatre", thus referring to the Maoist era. He consciously appealed to the memories of older Chinese people and - innocently mocking their resentments - wove them into the lyrics of the song On the way to Shaoshan (Rojas \& Chow, 2011, p. 167). The author clearly shows how much the aspiration vectors of the Chinese society have changed, as it is no longer interested in building socialism, but is instead fascinated by the American dream. Such distortion of classics seems to be "subversive" and iconoclastic. The choice of the song is intentional. At the turn of the $21^{\text {st }}$ century, there was a "Mao Zedong fever" in connection with one hundredth anniversary of his birth falling in 2003, and songs about Mao or from the period of his rule became popular once again.

2 In the Accidental Death of an Anarchist the actors satirically imitated Mao's manner of speaking, at the same time performing gestures from model operas (Ferrari, 2012, p. 237). 
The text below is an original song, well-known to the Chinese:

The wheels are spinning, the whistle is blowing

Our train is heading to Shaoshan

We pass mountains, we cross rivers

Towards pink clouds in the sky

Oh, towards pink clouds in the sky

Rays of sunshine fall into our compartments

And it is lively inside

It is really lively inside

An old Tibetan man is playing the zither

A Xinjiang girl is dancing

A Mongolian passenger is singing a song

We are singing all the way and travelling with a smile

Its version from the Accidental Death of an Anarchist:

The wheels are spinning, the whistle is blowing

Our train is heading to America

We pass mountains, we cross rivers

Towards pink clouds in the sky

Oh, towards pink clouds in the sky

The round, round American moon

American dollars float through the sky

Uncle Sam is playing the zither

The Statue of Liberty is dancing

We are all singing

We are singing all the way and travelling with a smile ${ }^{3}$

While criticism of Mao's government is sometimes found in films or literature, it usually does not desecrate his image. These days Mao is processed by pop culture, appears on merchandise, and if he is distorted, it is in a likeable or satirical way, as in the song from Meng Jinghui's play.

3 Translation of song lyrics by the author of the article. 
Will the iconoclasm of the image of the Chinese leader repeat itself? It is possible, as long as the cult of the current chairman, Xi Jinping, emerges. Sinologists increasingly draw attention to the discreetly developing, fledgling cult of China's leader Xi Jinping (e.g., Luqiu, 2016). "Since Xi Jinping, the Communist Party leader, took power two years ago, he has demanded that citizens, especially artists and writers, uphold party orthodoxy, and has warned against 'historical nihilism', or bleak depictions of the past that undermine the party's stature. Mr. $\mathrm{Xi}$ has taken particular umbrage at critics of the party who live off the party's largess" (Buckley, 2015).

With the revival of Confucianism and governmental support for it, it becomes possible that Xi Jinping will become like an emperor, exercising enlightened authoritarian rule and holding the mandate of heaven. However, the cult of Mao will still be present as a symbol of the victory of communism, and the Party celebrating his cult will at the same time be anointed to hold power.

\section{REFERENCES:}

Barmé, G. (2012). Red Allure and the Crimson Blindfold. China Perspectives, 2, 29-40. Retrieved from: http://journals.openedition.org/chinaperspectives/5859.

Buckley, C. (2014). Beijing Formally Charges Writer Who Published Memoirs of Victims of Mao Era. Retrieved from: https://www.nytimes.com/2014/10/24/world/asia/ beijing-charges-writer-tie-liu.html?_r=1.

Buckley, C. (2015). Mocking Mao Backfires for Chinese TV Host. Retrieved from: https:// sinosphere.blogs.nytimes.com/2015/04/09/joking-about-mao-lands-tv-host-inhot-water/?_r=0.

Cheek, T. (2008). The Multiple Mao's of Contemporary China. Harvard Asia Quarterly, 11(2-3), 14-25.

Coonan, C. (2011). Ai Weiwei: Seeds of an Iconoclast. Retrieved from: http://www.independent.co.uk/news/people/profiles/ai-weiwei-seeds-of-an-iconoclast-2265474. html.

Dal Lago, F. (1999). Personal Mao: Reshaping an Icon in Contemporary Chinese Art. Art Journal, 58(2), 46-59. DOI: 10.2307/777948.

Debin, M.L. (2018). Ai Weiwei, Kui Hua Zi (Sunflower Seeds). Retrieved from: https:// smarthistory.org/ai-weiwei-kui-hua-zi-sunflower-seeds/.

Dirlik, A. (2012). Mao Zedong in Contemporary Chinese Official Discourse and History. China Perspectives, 2, 17-27.

Dong, D. (2012). Worship, Reflection, Empirical Research. China Perspectives, 2, 55-59. Ferrari, R. (2012). Pop Goes the Avant-Garde: Experimental Theatre in Contemporary China. London, New York, Calcutta: Seagull Books. 
Kasarełło, L. (2011). Chińska kultura symboliczna. Jej wspótczesne metamorfozy w literaturze, teatrze i malarstwie. Warszawa: Wydawnictwo Akademickie Dialog.

Keith, R.C. (2004). History, Contradiction, and the Apotheosis of Mao Zedong. China Review International, 11(1), 1-9. DOI: 10.1353/cri.2005.0023.

Lam, W. (2012). The Maoist Revival and the Conservative Turn in Chinese Politics. China Perspectives, 2, 5-15.

Landsberger, S. (2002). The Deification of Mao: Religious Imagery and Practices during the Cultural Revolution and Beyond. In: Woei Lien Chong (ed.), China's Great Proletarian Cultural Revolution: Master Narratives and Post-Mao Counternarratives (pp. 139-184). Lanham: Rowman \& Littlefield Publishers.

Lecturer Fired in China's Shandong After He Criticized Chairman Mao (2017). Retrieved from: http://www.chinesepen.org/english/lecturer-fired-in-chinas-shandong-afterhe-criticized-chairman-mao.

Leese, D. (2011). Mao Cult: Rhetoric and Ritual in China's Cultural Revolution. Cambridge: Cambridge University Press.

Li, X. (2010). Apathy and Deconstruction in Post-89 Art: Analyzing the Trends of "Cynical Realism" and "Political Pop". In: H. Wu \& P. Wang (eds.), Contemporary Chinese Art: Primary Documents (pp. 157-166). New York: The Museum of Modern Art.

Lu, R. (2014). China's New Class Hierarchy: A Guide. Retrieved from: http://foreignpolicy.com/2014/04/25/chinas-new-class-hierarchy-a-guide/.

Luqiu, L.R. (2016). The Reappearance of the Cult of Personality in China. East Asia: An International Quarterly, 33(4), 289-307. DOI: 10.1007/s12140-016-9262-x.

Mao Zedong, A Prosecutor of Religions, Is Now Worshiped Like a God (2016). Retrieved from: http://www.asianews.it/news-en/Mao-Zedong,-a-persecutor-of-religions,-isnow-worshiped-like-a-god-39515.html.

McGregor, R. (2013). Partia. Sekretny świat komunistycznych władców Chin. Kraków: Wydawnictwo Uniwersytetu Jagiellońskiego.

Professor Dismissed as Political Advisor After Alleged Insult of Chairman Mao (2017). Retrieved from: http://www.globaltimes.cn/content/1027499.shtml.

Rojas, C., \& Chow, E. (2011). Rethinking Chinese Popular Culture: Cannibalizations of the Canon. New York: Routledge.

Skarżyński, R. (1998). Koncepcja gnozy Erica Voeglina. In: J. Skoczyński (ed.), Gnoza polityczna (pp. 29-37). Kraków: Wydawnictwo Uniwersytetu Jagiellońskiego.

Steinmuller, H. (2015). 'Father Mao' and the Country-Family: Mixed Feelings for Fathers, Officials, and Leaders in China. Social Analysis, 59(4), 83-100. DOI: https:// doi.org/10.3167/sa.2015.590406. The Unilever Series: Ai Weiwei: Sunflower Seeds: Interpretation Text. Retrieved from: http://www.tate.org.uk/whats-on/tate-modern/ exhibition/unilever-series/unilever-series-ai-weiwei-sunflower-seeds/unilever.

Umińska, M. (1994). Słowo od tłumacza. In: E. Voegelin, Lud Boży (pp. 5-12). Kraków: Wydawnictwo Znak.

Wardęga, J. (2014). Chiński nacjonalizm. Rekonstruowanie narodu w Chińskiej Republice Ludowej. Kraków: Wydawnictwo Uniwersytetu Jagiellońskiego. 
Wasserstrom, J. (2010). Three Ways of Looking at the PRC's Latest Campaigns. Harvard Asia Quarterly, 13(2), 10-12.

Wenguang, H., \& Pin, H. (2015). Uderzenie w czerń. Morderstwo, pieniądze i walka o władzę w Chinach. Wołowiec: Czarne.

Voegelin, E. (1998). Lud Boży. Kraków: Wydawnictwo Znak.

Xin, X. (2009). Sixty Years of Chinese Icons. Retrieved from: http://www.chinatoday.com. cn/ctenglish/se/txt/2009-01/22/content_175681.htm. 